\title{
Biomass Valorization: Sustainable Methods for the Production of Hemicellulolytic Catalysts from Thermoanaerobacterium thermostercoris strain BUFF
}

\author{
Ilaria Finore ${ }^{1}(\mathbb{D})$, Ida Romano ${ }^{1}$, Luigi Leone ${ }^{1}$, Paola Di Donato ${ }^{1,2}\left(\mathbb{D}\right.$, Barbara Nicolaus ${ }^{1}$, Annarita Poli ${ }^{1, *(\mathbb{D})}$ and \\ Licia Lama ${ }^{1}$
}

Citation: Finore, I.; Romano, I.; Leone, L.; Di Donato, P.; Nicolaus, B.; Poli, A.; Lama, L. Biomass

Valorization: Sustainable Methods for the Production of Hemicellulolytic

Catalysts from Thermoanaerobacterium thermostercoris strain BUFF. Resources 2021, 10, 115. https://doi.org/ $10.3390 /$ resources10110115

Academic Editors: Ezio Riggi, Raffaella Maria Balestrini and Edoardo Marco Napoli

Received: 30 July 2021

Accepted: 5 November 2021

Published: 10 November 2021

Publisher's Note: MDPI stays neutral with regard to jurisdictional claims in published maps and institutional affiliations.

Copyright: (c) 2021 by the authors. Licensee MDPI, Basel, Switzerland. This article is an open access article distributed under the terms and conditions of the Creative Commons Attribution (CC BY) license (https:/ / creativecommons.org/licenses/by/ $4.0 /)$.
1 Institute of Biomolecular Chemistry (ICB), Consiglio Nazionale delle Ricerche (CNR), Via Campi Flegrei 34, 80078 Pozzuoli, Italy; ilaria.finore@icb.cnr.it (I.F.); iromano@icb.cnr.it (I.R.); lleone@icb.cnr.it (L.L.); paola.didonato@icb.cnr.it (P.D.D.); bnicolaus@icb.cnr.it (B.N.); llama@icb.cnr.it (L.L.)

2 Department of Science and Technology, University of Naples Parthenope, Centro Direzionale, Isola C4, 80143 Naples, Italy

* Correspondence: apoli@icb.cnr.it; Tel.: +39-081-867-5311

\begin{abstract}
Processing and selection of fruits and vegetables generate high quantities of wastes that represent an economic and environmental issue for the agroindustry sector. According to the so-called "biorefinery" approach, this biomass can be exploited for the recovery of value-added molecules. In this study, the residues of industrial processing of tomato (Lycopersicon esculentum variety "Hybrid Rome"), fennel (Foeniculum vulgare), potato (Solanum tuberosum) and carrot (Daucus carota) were used as sole carbon sources to support cheap and sustainable microbial growth as well as the production of secondary metabolites (hydrogen and ethanol) by Thermoanaerobacterium thermostercoris strain BUFF, a thermophilic anaerobic microorganism isolated from buffalo-dung compost. Moreover, the use of hemicellulolytic enzymes of $T$. thermostercoris was assayed in the bioconversion reaction of the polymer fraction extracted from the rhizome of giant reed (Arundo donax) and of the leaves and stems of cardoon (Cynara cardunculus), dedicated non-food crops employed in energy supply.
\end{abstract}

Keywords: agro-waste biomass; hemicellulose; biorefinery; Thermoanaerobacterium thermostercoris; extremozymes; hydrogen; ethanol

\section{Introduction}

The circular economy is an alternative to the current linear, "make, use, dispose", economy model, which aims to keep resources in use for as long as possible to extract the maximum value from them whilst in use and to recover and regenerate products and materials at the end of their service life. It offers an opportunity to minimize the negative impacts of biomass's exploitation while maximizing the benefits from vegetable wastes and providing environmental, economic and societal benefits [1]. In addition, given the need to increase circularity of industrial systems to address limited resource availability, the development of the food waste biorefinery concept is also welcome, taking into account several critical aspects related to the technical feasibility of the processes at an industrial scale and their techno-economic potential, including available quantities of waste and a life-cyclebased environmental assessment [2]. However, the optimization of feedstock availability and transport should be systematically implemented to ensure that the profitability of biorefineries does not lead to trade-offs, such as increasing environmental impacts and externalities due to logistics [3]. Generally, when we refer to agro-industrial wastes, we are taking into consideration both lignocellulosic biomass, such as agricultural and forest residues; dedicated non-food crops, both herbaceous and woody as well as starchy biomass, from agricultural processing wastes. The main fraction of the vegetable wastes is represented by lignocellulosic residues, essentially consisting of cellulose, hemicellulose and lignin in variable proportions based on the plant source. The use of lignocellulosic 
wastes as renewable resources can reduce the dependence on fossil-based resources and contribute to sustainable waste management [4]. Therefore, the "biorefinery", starting from the valorization of waste biomass, realizes the biomass transformation processes for the integrated production of fuels, heat, fertilizers and derivatives for new markets [5], potentially leading to new substances and energy, starting from wastes subjected to various transformation processes such as thermal, chemical, thermochemical, physical and bioprocesses using bacteria and their enzymes [5,6]. Consumer chemicals, including acids, sugars and their derivatized forms, can be synthesized from agro-waste, with important results for nutraceutical and biomaterial applications [7].

In recent research activities, recovered vegetable biomass wastes have been subjected to a series of steps which, depending on the method used, can allow the isolation and the recovery of several biomolecules such as polysaccharides and polyphenols through integrated system approaches [8-12]. In general, the pre-treatment of lignocellulosic biomass is a preparatory phase for hydrolysis and causes the breakdown of the plant cell structure. It requires preparation steps that allow the cellulose to be freed in the first place from the lignocellulosic structure; for this purpose, numerous physical (mechanical shredding), chemical-physical, chemical and biological pre-treatment technologies have been developed to make cellulose and hemicellulose accessible from vegetable wastes [13]. Moreover, the extracted biopolymers in turn could be used as starting materials in order to achieve the hydrolyses products by enzymatic treatment (monosaccharides, oligo-saccharides, xylooligosaccharides, for example) that could find applications in several industrial sectors. In these reactions of bioconversion, bacterial extremophiles provide a valuable resource for exploitation in novel biotechnological processes [14]. Among the extremophiles, thermophilic microorganisms are of special interest owing to their advantages such as short fermentation time; production of heat stable macromolecules and metabolites; occurrence of metabolic reactions at the same high temperature that solubilize substrates; increased diffusion rates, ionization and solubility of chemicals; direct recovery of volatile products; expression of thermostable enzymes and the non-toxic nature of the bioproducts allowing applications in food and pharmaceutical industries [15]. The studies on thermophilic microorganisms have revealed that they are promising sources of novel catalysts which are suitable for industry demands. Thermophilic microorganisms produce numerous types of catalysts, e.g., amylases, phosphatases (including phytases), cellulases, hemicellulases, proteases, lipases, laccases and several other enzymes, also known as thermozymes, which are useful in different industries such as food, textiles and detergents, dairy and pharmaceuticals [16-18].

Agroindustry wastes have recently shown to be valuable feedstock in the microbiological field. Vegetable processing wastes, like other food processing residues, are rich in sugars, lipids, proteins and vitamins and therefore have a chemical composition that can support bacterial growth [19]. The bacterium T. thermostercoris was selected for this study since it is an interesting biotechnological strain. Indeed, T. thermostercoris is able to produce several hydrolytic biocatalysts such as hemicellulolytic enzymes thus being useful for the production of biofuel metabolites, such as hydrogen and ethanol. The potential of $T$. thermostercoris enzymes for biofuel production was tested by using the polysaccharide fraction (mostly cellulose and hemicellulose) recovered, by means of low-impacting extraction methods, from A. donax and C. cardunculus. In recent years, A. donax has received increasing interest as a non-food crop because of its high biomass yields, low production costs and flexibility of use [20] for the production of bioenergy/biofuels, through biological fermentation and in the direct combustion of biomass. Thanks to its high yield of biomass and the fiber composition, $A$. donax yields a large amount of bioethanol, generally higher than those obtained using other energy crops. It has recently been found that seeds of C. cardunculus can be used in the energy supply chain for the production of biodiesel, while the residual biomass can be exploited for the production of thermal energy [21].

The objective of the present study was to assess the feasibility to reuse agro-food industry wastes for the growth of Thermoanaerobacterium thermostercoris strain BUFF, a 
thermophilic anaerobic microorganism isolated from buffalo-dung compost, and then as promoters of the production of the bacterium's enzymatic pool. Finally, the enzymes produced by this way were tested for the bioconversion of the hemicellulolytic fraction of two most used energy crops, i.e., Arundo donax (giant reed) and Cynara cardunculus (cardoon). Overall, the goal was to exploit agro-wastes as an alternative to the standard substrates available on the market at high cost (for example growth media comprising yeast extract, peptone, meat extract, and so on), currently used for bacterial biomass and related enzymes of biotechnological interest.

\section{Materials and Methods}

\subsection{Waste Biomass}

Waste biomass deriving from industrial processing of tomato (Lycopersicon esculentum variety "Hybrid Rome"), fennel (Foeniculum vulgare), potato (Solanum tuberosum) and carrot (Daucus carota) was kindly supplied from Fontanella Industry (Salerno, Italy), Fenny s.r.l. (Pagani, Salerno, Italy), Amato V. "Sammy Export" (Pagani, Salerno, Italy) and Tafuri Brothers for Polli Industry (Battipaglia, Salerno, Italy), respectively. Rhizomes of Arundo donax and stems and leaves of Cynara cardunculus were provided by the Agraria Department of "Federico II" University, Naples, and were obtained from an experimental plantation located at the Sele river plain of Campania Region (Southern Italy, $40^{\circ} 61^{\prime} \mathrm{N}, 14^{\circ} 92^{\prime} \mathrm{E}, 30 \mathrm{~m}$ a.s.l.). Vegetable wastes were dried under vacuum until reaching constant weight in order to avoid presence of residual water and minced to comparable particle size for further use.

\subsection{Thermoanaerobacterium thermostercoris Culture Conditions}

Pre-culture of Thermoanaerobacterium thermostercoris strain BUFF $\left(\right.$ ATCC BAA-1776 ${ }^{\mathrm{T}}=$ DSM $22141^{\mathrm{T}}$ ) was performed at a temperature of $60^{\circ} \mathrm{C}$ in $25 \mathrm{~mL}$ of broth "TN" dispensed into $120 \mathrm{~mL}$ serum bottles with agitation of $100 \mathrm{rpm}$ in strict anaerobic conditions [22,23]. Culture medium contained (g/L): $\mathrm{NaCl} 10.0 ; \mathrm{KCl} 0.1 ; \mathrm{MgCl}_{2} \bullet \mathrm{H}_{2} \mathrm{O} 0.2 ; \mathrm{NH}_{4} \mathrm{Cl} 1.0 ; \mathrm{K}_{2} \mathrm{HPO}_{4}$ 0.3; $\mathrm{CaCl}_{2} \bullet 2 \mathrm{H}_{2} \mathrm{O}$ 0.1; cysteine- $\mathrm{HCl} 1.0$; yeast extract 2.0; tryptone 2.0; glucose 5.0; resazurin 0.001 . Before sterilization, the $\mathrm{pH}$ was adjusted at 6.5 with $1 \mathrm{M} \mathrm{NaOH}$ at room temperature. Routine growth was performed using a standard culture medium TN. After sterilization, the medium was also supplemented with $10 \mathrm{~mL} / \mathrm{L}$ of both filter-sterilized vitamins and trace element solutions from DSM medium 141 [24]. The ability of the strain to utilize different carbon sources for growth and hemicellulolytic enzyme production was investigated in a $1 \mathrm{~L}$ glass reactor. Cultures were set up at the above reported temperature in $0.5 \mathrm{Lt}$ of the anaerobic medium deprived of glucose and enriched at a final concentration of $5 \mathrm{~g} / \mathrm{L}$ with one of the following compounds: xylose, arabinose or xylan or at a final concentration of $10 \mathrm{~g} / \mathrm{L}$ with one of the following vegetable waste biomass: tomato, potato, carrot or fennel. The headspace was replaced with nitrogen gas. Growth was interrupted after $14 \mathrm{~h}$ (early stationary phase of growth) and evaluated by measuring the optical density at $\lambda 540 \mathrm{~nm}$; in addition, the fermentation end products were compared. All experiments were carried out in duplicate.

\subsection{Partial Enzyme Purification and Protein Content Determination}

The $500 \mathrm{~mL}$ of culture broths were centrifuged at 10,000 rpm for $40 \mathrm{~min}$, and the cell-free supernatants were precipitated with $80 \%$ ammonium sulphate and named " $\mathrm{PP}\left(\mathrm{NH}_{4}\right)_{2} \mathrm{SO}_{4}$ ". The crude enzymes were dissolved in $50 \mathrm{mM}$ sodium acetate buffer $\mathrm{pH} 5.6$ and dialyzed against the same buffer at a temperature of $4{ }^{\circ} \mathrm{C}$ by using Visking dialysis tubing with 14,000 Da cut-off. The protein concentration was determined by using a BioRad protein assay kit with bovine serum albumin as standard protein according to the Bradford method [25].

\subsection{Enzymatic Assays}

Xylanase activity was assayed by using $2 \%$ birchwood xylan as the substrate. The mixture, containing $0.5 \mathrm{~mL}$ of an appropriate dilution of the enzyme and $0.5 \mathrm{~mL}$ of the 
substrate, was incubated at $60^{\circ} \mathrm{C}$ for $20 \mathrm{~min}$. The quantity of reducing sugars liberated was determined using 3,5-dinitrosalicylic acid (DNS method) [26,27]. One unit of xylanase activity was expressed as $\mu \mathrm{mol}$ of reducing sugars (xylose equivalent) released in $1 \mathrm{~min}$ under the abovementioned conditions. $\beta$-xylosidase, $\alpha$-arabinofuranosidase, $\beta$-glucosidase, $\alpha$-galactosidase, $\beta$-galactosidase and $\beta$-fucosidase assays were based on the release of $p$-nitrophenol from $1 \mathrm{mM}$ of $p$-nitrophenyl- $\beta$-D-xylopyranoside, $p$-nitrophenyl- $\alpha$-Larabinofuranoside, $p$-nitrophenyl- $\beta$-D-glucopyranoside, $p$-nitrophenyl- $\alpha$-D-galactopyranoside, $p$-nitrophenyl- $\beta$-D-galactopyranoside and $p$-nitrophenyl- $\beta$-D-fucopyranoside, respectively, using appropriately diluted enzyme solution at $60^{\circ} \mathrm{C}$ for $20 \mathrm{~min}$ in $1 \mathrm{~mL}$ of $50 \mathrm{mM}$ sodium acetate buffer $\mathrm{pH} 5.6$ as final volume [28]. The acetyl-xylan esterase assay was based on the release of $\mathrm{p}$-nitrophenol from $0.1 \mathrm{mM}$ of p-nitrophenyl-acetate by the enzyme solution at $60{ }^{\circ} \mathrm{C}$ in $50 \mathrm{mM}$ sodium acetate buffer at $\mathrm{pH} 5.6$ for $20 \mathrm{~min}$ in $2 \mathrm{~mL}$ as final volume [29].

\subsection{Biochemical Characterization of Enzyme Activities}

The optimum $\mathrm{pH}$ for the enzyme activities was determined by assaying the enzymes in reaction mixtures under standard conditions by varying the $\mathrm{pH}$ from 3.0 to 10.0 using glycine- $\mathrm{HCl}$ buffer ( $\mathrm{pH} 3.0)$, acetate buffer ( $\mathrm{pH} 3.5-4.0-4.6-5.0-5.6)$, phosphate buffer (pH 6.0-6.5), Tris- $\mathrm{HCl}(\mathrm{pH} 7.0)$ and glycine-NaOH buffer ( $\mathrm{pH}$ 8.6-9.0-10.0) for each appropriate $\mathrm{pH}$ range. The optimum temperature was determined by assaying the enzyme activity in $50 \mathrm{mM}$ acetate buffer, $\mathrm{pH} 5.6$ at temperatures ranging from 40 to $90^{\circ} \mathrm{C}$. In both cases, the enzyme preparation from standard growth conditions of $T$. thermostercoris was employed. Thermal stability determination of xylanase, $\beta$-xylosidase, $\alpha$-arabinofuranosidase and acetyl-xylan esterase was carried out by pre-incubating the samples in a temperature range $65-80{ }^{\circ} \mathrm{C}$ at various time intervals; after that the residual activities were determined under standard assay conditions and expressed as \% with the respect to the same enzyme assayed without pre-incubation $(100 \%)$.

\subsection{Electrophoresis and Zymogram}

Protein samples were analyzed by sodium dodecyl sulphate-polyacrylamide gel electrophoresis (SDS-PAGE) using 10\% acrylamide as resolving gel and 5\% stacking gel according to the method of Laemmli [30]. The molecular mass was determined by using a molecular mass marker (Pharmacia). The proteins on the gel were visualized by staining with silver or Coomassie Brilliant Blue R-250 according to the manufacturer's instructions. The zymogram analysis was performed according to Martinez [31]. In the case of xylanase, protein samples were denatured by heating at $70{ }^{\circ} \mathrm{C}$ for $10 \mathrm{~min}$ in sample buffer containing $\beta$-mercaptoethanol and then subjected to a normal 10\% SDS-PAGE gel containing $0.5 \%$ $(w / v)$ xylan. After electrophoresis, the gel was washed twice with $20 \%(v / v)$ isopropanol in $50 \mathrm{mM}$ sodium citrate buffer (SCB) $\mathrm{pH} 5.4$ for 30 min each at room temperature, followed by two washes of $30 \mathrm{~min}$ each in SCB (pH 5.4). The gel was incubated in SCB (pH 5.6) at $60{ }^{\circ} \mathrm{C}$ for $30 \mathrm{~min}$ for reaction and then stained with $0.1 \%(w / v)$ Congo red containing $5 \%(v / v)$ ethanol for $30 \mathrm{~min}$, destained with $1 \mathrm{M} \mathrm{NaCl}$ (15 min, 2 times). The xylanase activity was visible as a clear band against a red background. The $\beta$-xylosidase and $\alpha$-arabinofuranosidase activities in the gel were detected by developing a zymogram against $50 \mu \mathrm{g} / \mathrm{mL}$ 4-methylumbelliferyl- $\beta$-D-xyloside or $50 \mu \mathrm{g} / \mathrm{mL}$ 4-methylumbelliferyl$\alpha$-arabinofuranoside as substrate, respectively, prepared in $50 \mathrm{mM}$ sodium citrate buffer (pH 5.6). After the electrophoretic run, the gel was immersed in substrate solution for $15 \mathrm{~min}$ at $70{ }^{\circ} \mathrm{C}$ in the dark. The enzyme bands in the gel were visualized under UV light at $\lambda 365 \mathrm{~nm}$. The acetyl-xylan esterase activity in the gel was revealed by incubating the gel, after the electrophoretic run, in $20 \%(v / v)$ isopropanol then in $50 \mathrm{mM}$ sodium acetate buffer $\mathrm{pH} 5.6$ and finally in $2 \mathrm{mM} p$-nitro-phenyl acetate. Yellow bands after $10 \mathrm{~min}$ of incubation appeared in the presence of the enzyme. 


\subsection{Ethanol and Hydrogen Production by T. thermostercoris}

The cell-free supernatants were tested for ethanol content using the Megazyme KETOH kit according to the manufacturer's instructions. Hydrogen was detected and quantified by gas chromatography (Focus GC-Thermo Scientific Instrument, 3m Hayesep $\mathrm{Q}$ column) by injection of $1 \mathrm{~mL}$ of headspace. The temperatures of the thermal conductivity detector, injector and analytical column were 200,50 and $50{ }^{\circ} \mathrm{C}$, respectively. Nitrogen was used as a carrier gas at a flow rate of $20 \mathrm{~mL} / \mathrm{min}$. Hydrogen was quantified using an external calibration curve and expressed as $\mathrm{mL}$ of $\mathrm{H}_{2}$ produced from $1 \mathrm{~L}$ of culture in $1 \mathrm{~h}$.

\subsection{Enzymatic Degradation of Hemicellulolytic Extracts from Cynara Cardunculus and Arundo Donax Biomass}

Next, $1 \mathrm{~g}$ of dry stem and leaves from Cynara cardunculus $(\mathrm{C})$ and $1 \mathrm{~g}$ of dry rhizomes from Arundo donax (A) were treated for hemicellulosic fraction extraction. For this purpose, a previously reported procedure [13,32] was applied, and almost $17.6 \%$ and $17 \%(w / w)$, respectively, of the dried biomass was recovered. The lyophilized material, from C. cardunculus (CK) and from A. donax (AK), respectively, was used as substrate for bioconversion reactions. Enzymatic digestion $(2 \mathrm{~mL})$ of $8 \mathrm{mg}$ of hemicellulosic material extracted from $C$. cardunculus (CK) and A. donax (AK), solubilized in $50 \mathrm{mM}$ sodium acetate buffer ( $\mathrm{pH}$ 5.6), was carried out by incubating the partially purified samples with ammonium sulphate enzymatic solution obtained from fennel growth ( $4.86 \mathrm{mg}$ of total proteins) for $24 \mathrm{~h}$ at $60{ }^{\circ} \mathrm{C}$. All enzymatic reactions were performed in duplicate, in sealed glass vessels, under magnetic stirring and stopped by cooling in an ice bath. The results of hydrolysis reactions were estimated through the reducing sugar assay [26], evaluating the optical density at $\lambda 546 \mathrm{~nm}$; the contribution of unhydrolyzed substrate was subtracted from the values obtained after $24 \mathrm{~h}$ of incubation. The reaction products were further analyzed by thin layer chromatography (TLC) in solvent, $n-\mathrm{BuOH} / \mathrm{AcOH} / \mathrm{H}_{2} \mathrm{O}, 6: 2: 2(v / v)$, to determine the mono- and oligosaccharidic composition of reaction products.

\section{Results and Discussion}

\subsection{T. thermostercoris Growth Test on Different Substrates for Hydrogen and Ethanol Production}

The production costs for microbial biomass, enzymes and other metabolites represent the great obstacle to the success of a possible application in the industrial field, and therefore the optimization of the growth conditions are important and crucial in defining the optimal production while limiting costs. With this purpose $T$. thermostercoris strain BUFF, a nonspore-forming, thermophilic and anaerobic Gram-positive staining microorganism, was grown on different substrates including agriculture wastes as reported in the Materials and Methods section. In Table 1, the parameters related to absorbance, production of hydrogen and ethanol after $14 \mathrm{~h}$ of growth in a glass bioreactor are reported (Figure S1).

Table 1. T. thermostercoris strain BUFF growth on $\mathrm{TN}$ growth medium plus different substrates after $14 \mathrm{~h}$ of incubation at temperature of $60^{\circ} \mathrm{C}$.

\begin{tabular}{lccc}
\hline \multicolumn{1}{c}{ Culture Medium } & O.D. $\mathbf{~ 5 4 0 ~} \mathbf{~ m ~}$ & $\begin{array}{c}\mathbf{H}_{\mathbf{2}} \\
(\mathbf{m L} / \mathbf{L} / \mathbf{h})\end{array}$ & $\begin{array}{c}\mathbf{C H}_{\mathbf{2}} \mathbf{C H} \\
(\mathbf{g} / \mathbf{L})\end{array}$ \\
\hline $\mathrm{TN}+$ xylose & $0.707 \pm 0.021$ & $20 \pm 0.02$ & $0.1331 \pm 0.08$ \\
\hline $\mathrm{TN}+$ glucose & $0.853 \pm 0.016$ & $24.7 \pm 0.02$ & $0.1433 \pm 0.02$ \\
\hline $\mathrm{TN}+$ arabinose & $0.637 \pm 0.013$ & $14.8 \pm 0.022$ & $0.1142 \pm 0.01$ \\
\hline $\mathrm{TN}+$ xylan & $0.980 \pm 0.024$ & $27 \pm 0.05$ & $0.1565 \pm 0.01$ \\
\hline $\mathrm{TN}+$ carrot waste & $1.182 \pm 0.011$ & $31 \pm 0.03$ & $0.2401 \pm 0.02$ \\
\hline $\mathrm{TN}+$ tomato waste & $0.964 \pm 0.029$ & $5.3 \pm 0.01$ & $0.0073 \pm 0.0021$ \\
\hline $\mathrm{TN}+$ fennel waste & $1.154 \pm 0.021$ & $35 \pm 0.05$ & $0.1292 \pm 0.01$ \\
\hline TN + potato waste & $0.475 \pm 0.011$ & $0.16 \pm 0.02$ & n.d. \\
\hline n.d.: not determined. & & &
\end{tabular}


A higher yield in terms of growth (O.D. $\lambda 540 \mathrm{~nm}$ ), compared to the standard culture medium containing glucose ( $\mathrm{TN}+$ glucose) or the other added sugars, occurred when the microorganism grew in the media enriched with carrot, fennel and tomato wastes. On the contrary, potato waste did not support growth well. Moreover, the greatest production of hydrogen took place when the bacterium was grown on fennel waste $(35 \mathrm{~mL} / \mathrm{L} / \mathrm{h}$ $\mathrm{H}_{2}$ ) followed by the production carried out on carrot waste and xylan. In the case of ethanol production, the maximum yield was found for cell growth conducted on carrot waste followed by growth on xylan. These results showed the ability of Thermoanaerobacterium thermostercoris strain BUFF to produce hydrogen and ethanol when grown by using agro-industrial vegetable wastes as main carbon sources. The production of hydrogen through biological processes represents a new area of biotechnology development for the production of bioenergy. The cost-effective production of biofuels by bacterial fermentation on economically competitive substrates such as agro-industrial waste for the improvement of hydrogen yields could become commercially competitive. In addition, biological conversion of biomass into ethanol and hydrogen, through the combination of hemicellulolytic enzyme production, hydrolysis of hemicellulose and fermentation in a single step, could provide new insights into a lower cost process [33,34]. Utilization of the waste biomass for production of value-added products through biological intervention not only helps to combat environmental pollution but also contributes significantly to the economy.

\subsection{Enzyme Production of T. thermostercoris in Selected Growth Media}

The presence of hemicellulolytic enzyme activities was investigated in all cell-free supernatants partially purified after the addition of $\left(\mathrm{NH}_{4}\right)_{2} \mathrm{SO}_{4}$ at $80 \%$ saturation. The enzyme assays, conducted as reported in the Materials and Methods section, were expressed as specific activity ( $\mathrm{U} / \mathrm{mg}$ protein). In Figure 1 it is possible to observe that the production of xylanase enzyme was higher when the strain BUFF was grown on xylose with a specific activity of $8 \mathrm{U} / \mathrm{mg}$. Moreover, the specific activity of xylanase, when compared to standard medium containing glucose $(1.4 \mathrm{U} / \mathrm{mg})$, was found to be higher on the waste of tomato $(2.1 \mathrm{U} / \mathrm{mg})$ and carrot $(1.8 \mathrm{U} / \mathrm{mg})$.

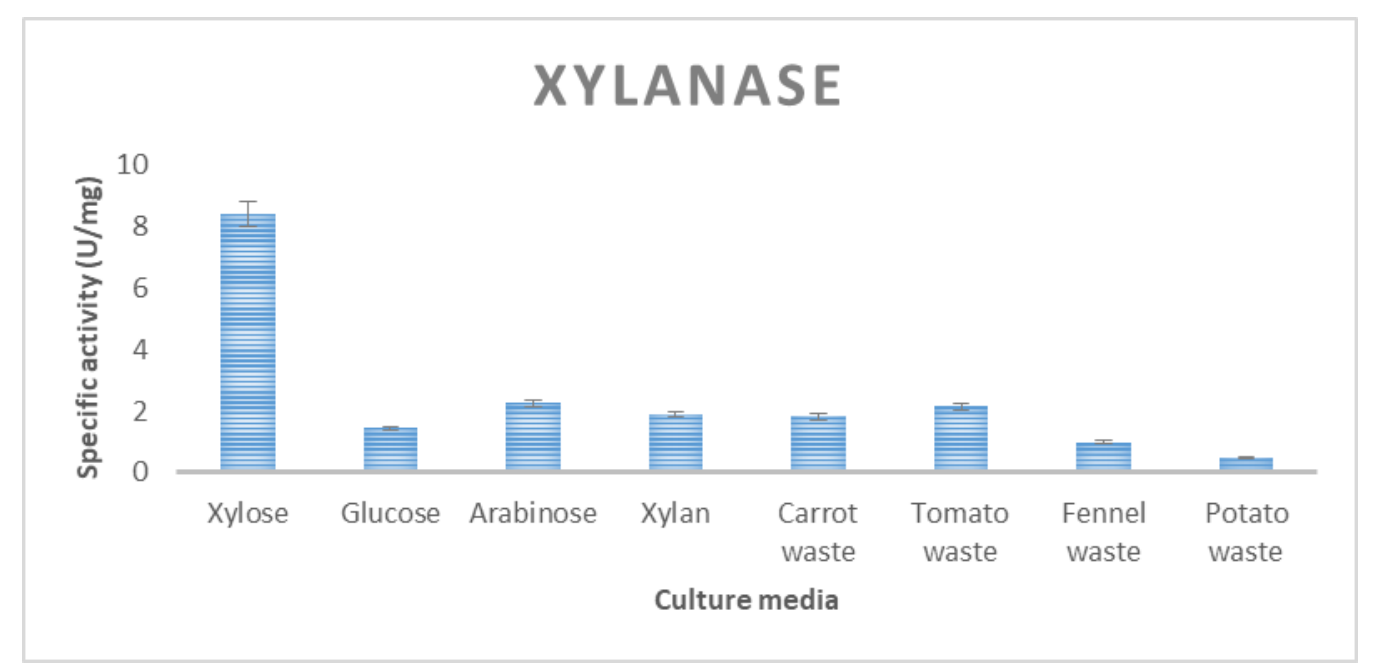

Figure 1. Xylanase specific activity produced by strain BUFF on TN medium containing the indicated carbon source or biomass.

Similarly for beta-xylosidase the greatest production was obtained from the growth conducted on xylose with $1158 \mathrm{U} / \mathrm{mg}$, while from the analysis of the growth on vegetable waste compared to the growth on glucose $(266 \mathrm{U} / \mathrm{mg})$, the results showed good yields on tomato $(405 \mathrm{U} / \mathrm{mg})$, fennel $(284 \mathrm{U} / \mathrm{mg}$ ) and carrot $(274 \mathrm{U} / \mathrm{mg})$ wastes (Figure 2). 


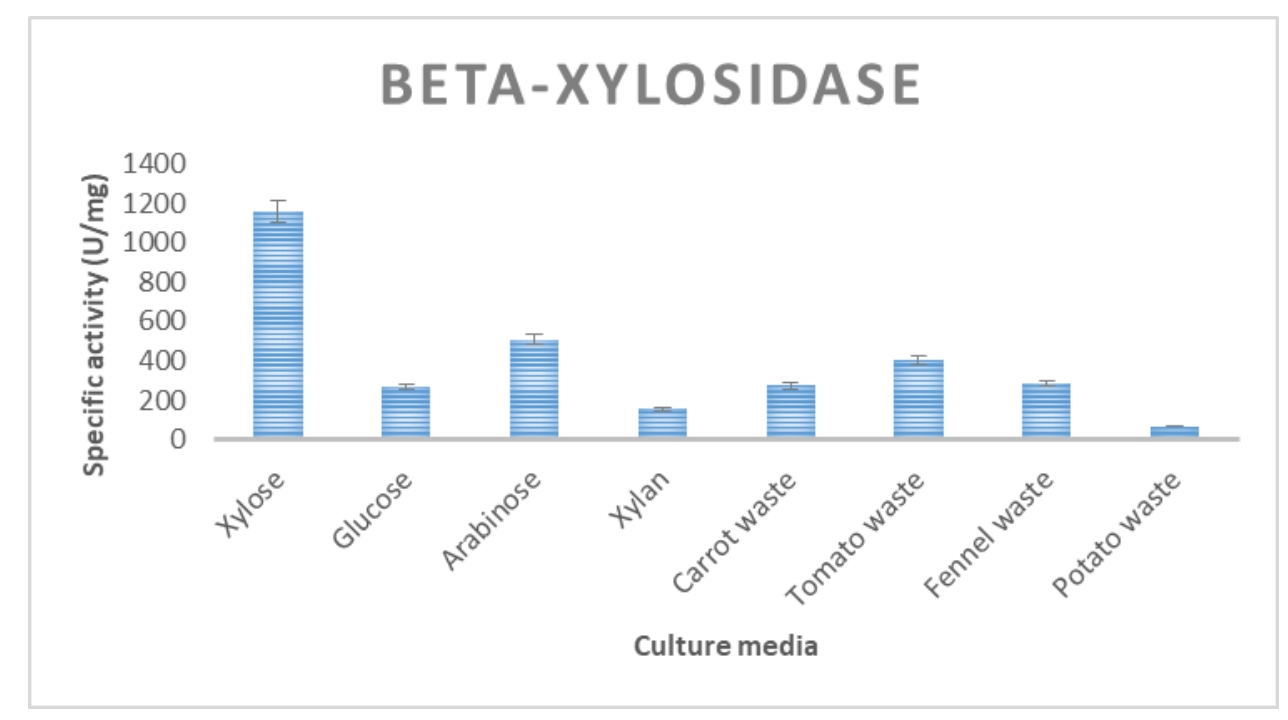

Figure 2. Beta-xylosidase specific activity produced by strain BUFF on TN medium containing the indicated carbon source or biomass.

In the case of the alpha-arabinofuranosidase enzyme, the higher enzymatic production was found in the standard culture medium with glucose $(4092 \mathrm{U} / \mathrm{mg})$ as carbon source, followed by growth on xylose $(1931 \mathrm{U} / \mathrm{mg}$ ) and arabinose $(1263 \mathrm{U} / \mathrm{mg})$; taking into account vegetable wastes, the production of the enzyme was found to be higher in culture media enriched with potato waste $(882 \mathrm{U} / \mathrm{mg})$ (Figure 3$)$.

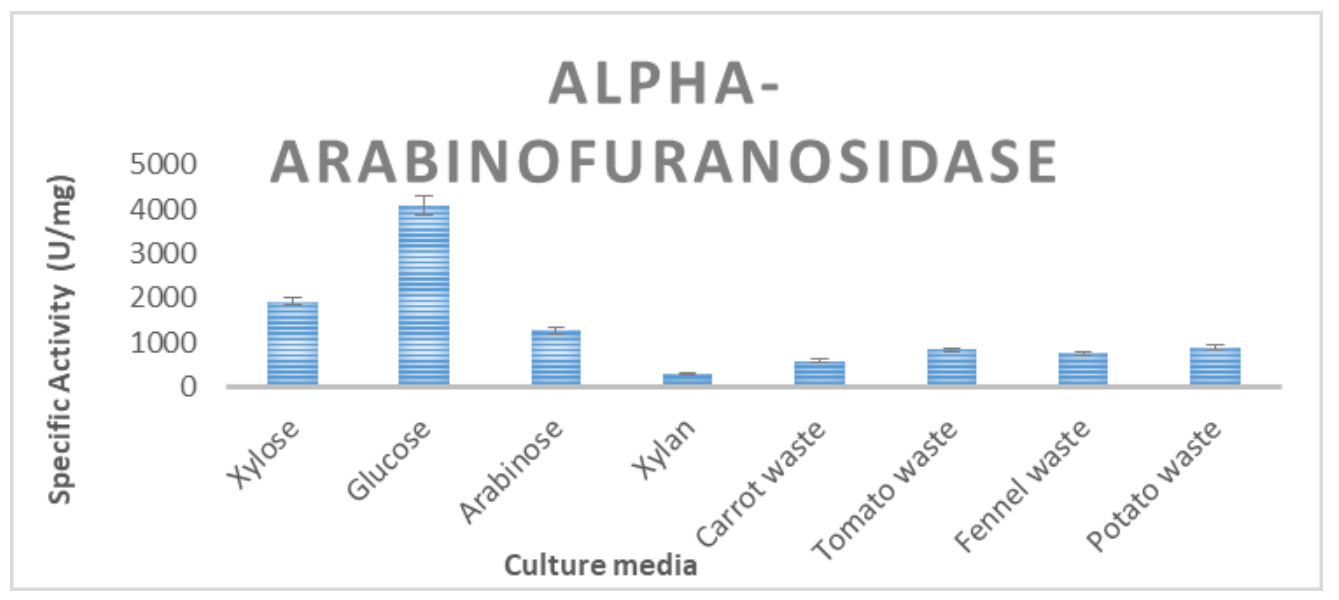

Figure 3. Alpha-arabinofuranosidase specific activity produced by strain BUFF on TN medium containing the indicated carbon source or biomass.

Interestingly, production of acetyl-xylan esterase was detected in the case of the T. thermostercoris strain BUFF grown on xylose as predominant carbon source reaching a specific activity of $11,961 \mathrm{U} / \mathrm{mg}$; among the vegetable waste tested, fennel and potato wastes showed a higher enzyme production with the respect to glucose $(4302 \mathrm{U} / \mathrm{mg})$, with specific activity values of 6019 and $5411 \mathrm{U} / \mathrm{mg}$, respectively. The waste of the tomato in the growth media, on the other hand, was found to inhibit this enzymatic activity (Figure 4).

As regards alpha-galactosidase enzyme, it was found that the greatest production was observed in microbial growth enriched with tomato waste $(1194 \mathrm{U} / \mathrm{mg})$ followed by growth on fennel waste $(587 \mathrm{U} / \mathrm{mg}$ ) (Figure 5). 


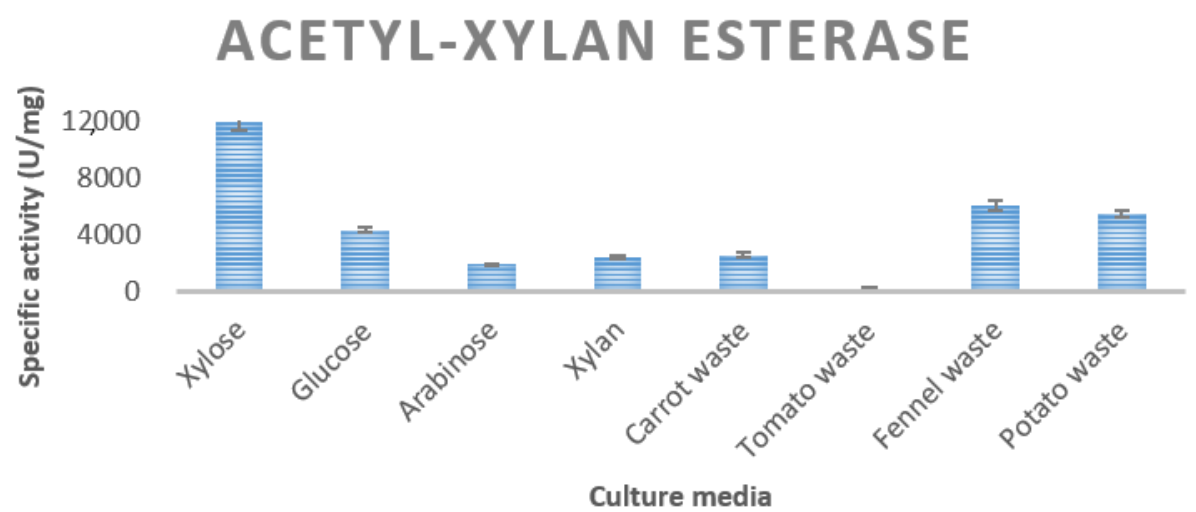

Figure 4. Acetyl-xylan esterase specific activity produced by strain BUFF on TN medium containing the indicated carbon source or biomass.

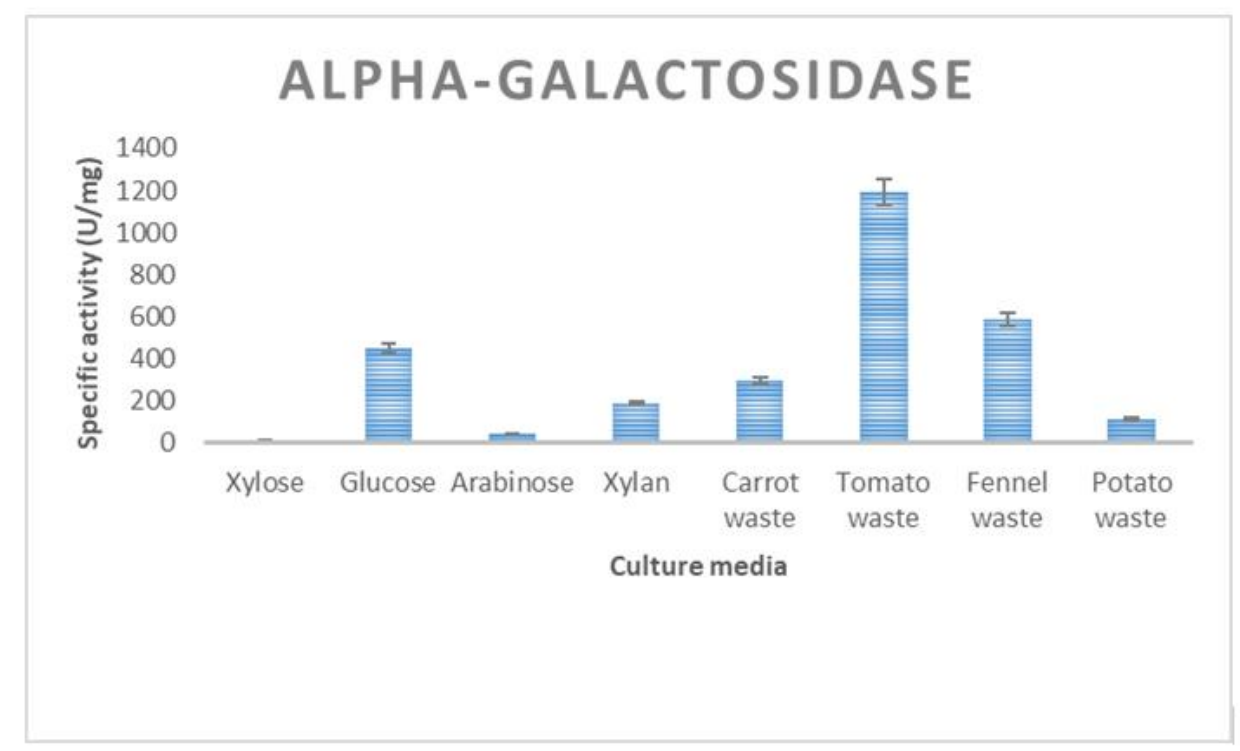

Figure 5. Alpha-galactosidase specific activity produced by strain BUFF on TN medium containing the indicated carbon source or biomass.

For the beta-galactosidase activity, bacterial growth on the medium containing arabinose substrate produced the greatest amount of the enzyme with a specific activity of $3800 \mathrm{U} / \mathrm{mg}$; all vegetable wastes tested, compared to the standard growth conducted on glucose $(167 \mathrm{U} / \mathrm{mg})$, produced beta-galactosidase to a greater extent. In the case of tomato, fennel, carrot and potato wastes, the specific activity recorded was 3773, 1139, 417 and $322 \mathrm{U} / \mathrm{mg}$, respectively (Figure 6).

The greatest production of beta-fucosidase enzyme occurred in the culture medium enriched with vegetable waste from the tomato, showing a specific activity of $5725 \mathrm{U} / \mathrm{mg}$, followed by the growth on arabinose as substrate $(4886 \mathrm{U} / \mathrm{mg})$. The other vegetable wastes tested, compared to the standard growth on glucose $(216 \mathrm{U} / \mathrm{mg})$, produced comparable levels of beta-fucosidase ranging from $476 \mathrm{U} / \mathrm{mg}$ in the case of potato up to $652 \mathrm{U} / \mathrm{mg}$ in the case of fennel waste (Figure 7).

Finally, the beta-glucosidase activity was mainly produced when the microorganism was grown in the presence of arabinose as main substrate $(15,955 \mathrm{U} / \mathrm{mg})$; among vegetable wastes analyzed, in the case of tomato and potato wastes, specific activity of 2576 and $2714 \mathrm{U} / \mathrm{mg}$ were registered, respectively, compared to growth on glucose (826 U/mg) (Figure 8). 


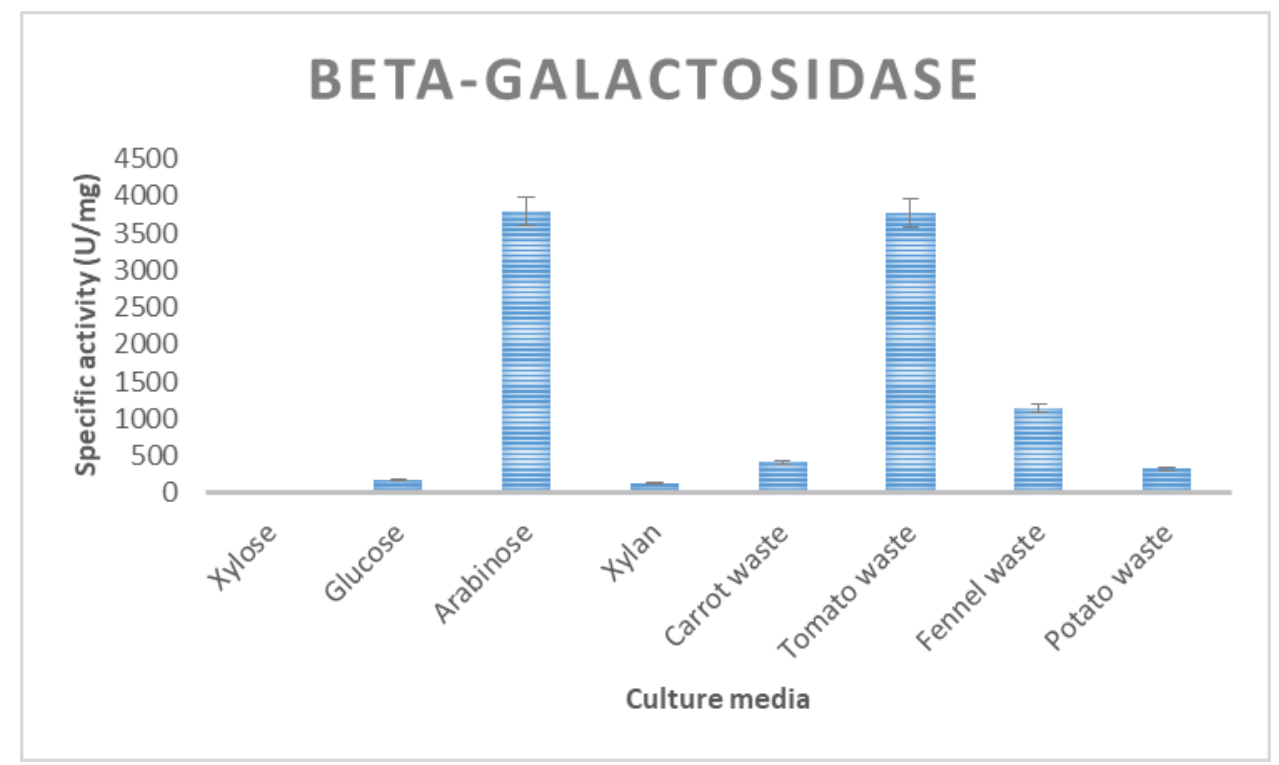

Figure 6. Beta-galactosidase specific activity produced by strain BUFF on TN medium containing the indicated carbon source or biomass.

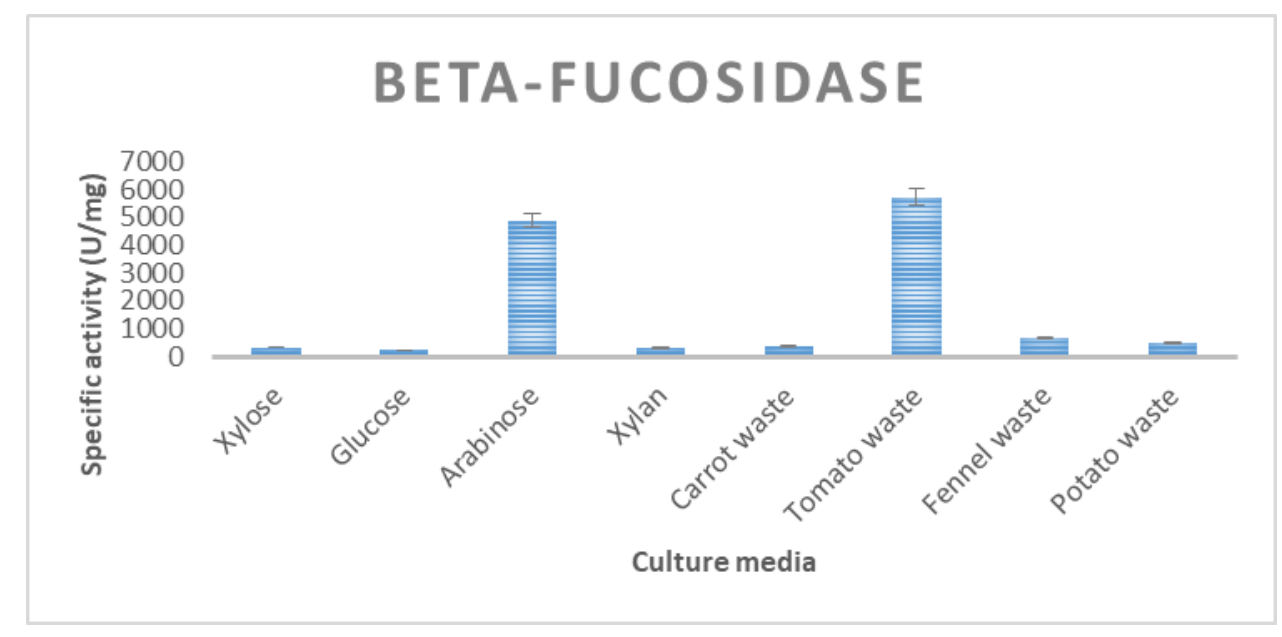

Figure 7. Beta-fucosidase specific activity produced by strain BUFF on TN medium containing the indicated carbon source or biomass.

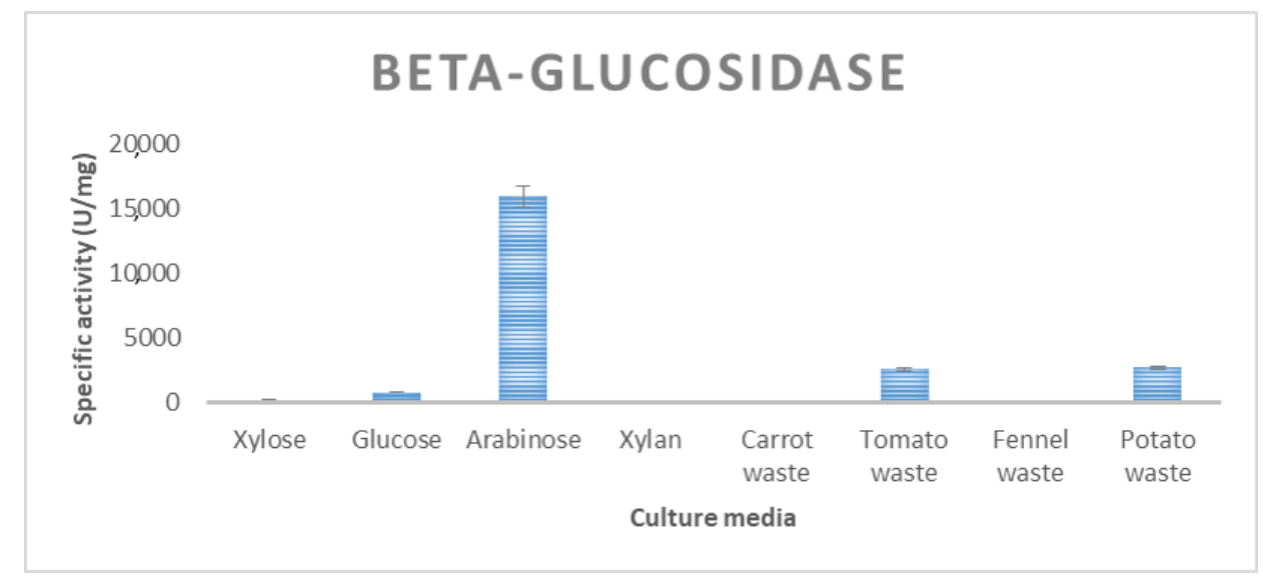

Figure 8. Beta-glucosidase specific activity produced by strain BUFF on $\mathrm{N}$ medium containing the indicated carbon source or biomass. 
The results showed that the composition of the biomass present in the growth media (vegetable biomass and sugars) influenced the production of the enzymatic activities. Indeed, carrot residues are composed mainly of pectin/hemicellulose/cellulose in the following ratio: 3.88:12.3:51.6 [35], while potato residues are composed mainly of starch/hemicellulose/cellulose according to the following ratio 67.5:9.2:1.2 [36]. Tomato waste's polysaccharide fraction is mainly composed of xyloglucan [37]; a similar composition has been found for fennel waste's polysaccharide fraction [10]. The higher production of xylanase, beta-xylosidase and acetyl-xylan esterase obtained with tomato and fennel wastes can be correlated with the chemical composition of the wastes (as reported above). In the case of the low acetyl-xylan esterase activity it could be argued that its expression depends upon the acetylation degree of the polysaccharide. As reported in the literature, "the degree of $O$-acetylation can vary depending on species, tissue type, and developmental state" of the plant source; therefore, it can be hypothesized that the obtained results are due to different degrees of acetylation in the polysaccharide fractions.

In Table 2, production of the enzymatic activities is summarized, and bold indicates the enzyme activities obtained from microbial growth carried out on agro-industrial wastes, with values greater than enzyme activity recorded on glucose medium (standard growth condition). These results indicated the importance of using different biomass sources to encourage the production of specific enzymes in a sustainable way by exploiting surplus biomass, disposal of which affects the costs faced by companies.

Table 2. Enzymatic production of the microorganism T. thermostercoris strain BUFF grown on culture media enriched with agro-industrial wastes in comparison with standard growth medium (glucose). One unit of enzyme was defined as the activity releasing $1 \mu \mathrm{mol}$ of $p$-nitrophenol in $20 \mathrm{~min}$ at $60^{\circ} \mathrm{C}$.

\begin{tabular}{lccccc}
\hline Enzyme Activity (U/mg) & Glucose & Carrot & Fennel & Potato & Tomato \\
\hline Xylanase & $1.4 \pm 0.01$ & $1.8 \pm 0.1$ & $0.9 \pm 0.01$ & $0.5 \pm 0.08$ & $2.14 \pm 0.8$ \\
\hline$\beta$-xylosidase & $266 \pm 21$ & $274 \pm 15$ & $284 \pm 13$ & $115 \pm 7.2$ & $405 \pm 15$ \\
\hline$\alpha$-arabinofuranosidase & $4092 \pm 34$ & $587 \pm 13$ & $754 \pm 8.5$ & $881 \pm 21$ & $831 \pm 18$ \\
\hline Acetyl-xylan esterase & $4302 \pm 28$ & $2546 \pm 13$ & $6019 \pm 34$ & $5411 \pm 91$ & 0 \\
\hline$\alpha$-galactosidase & $485 \pm 19$ & $335 \pm 12$ & $588 \pm 9$ & $168 \pm 6$ & $1194 \pm 31$ \\
\hline$\beta$-galactosidase & $167 \pm 11$ & $417 \pm 18$ & $1139 \pm 15$ & $322 \pm 7$ & $3773 \pm 43$ \\
\hline$\beta$-fucosidase & $216 \pm 7.6$ & $519 \pm 23$ & $1018 \pm 19$ & $476 \pm 9$ & $5725 \pm 47$ \\
\hline$\beta$-glucosidase & $827 \pm 15$ & $347 \pm 7$ & $476 \pm 12$ & $2714 \pm 40$ & $2576 \pm 33$ \\
\hline
\end{tabular}

In order to study the potential industrial applications of these enzymes, biochemical characterization is an indispensable step for biotechnological purposes.

Therefore, to identify the optimal chemical-physical parameters of the enzymatic activities produced by the microorganism $T$. thermostercoris strain BUFF, activity tests were carried out at different $\mathrm{pH}$ and temperatures values under standard conditions; in addition, the thermal stability assay and the determination of molecular weights, as described in the Materials and Methods section, were also conducted.

In Table 3 the optimal temperature and $\mathrm{pH}$ values, in addition to estimated molecular weights from SDS-PAGE analysis, are also reported. In most cases, the optimal temperature for the studied enzymes ranged from 60 to $80{ }^{\circ} \mathrm{C}$. Regarding the optimal $\mathrm{pH}$ value, in the case of acetyl-xylan esterase it was found in acidic medium (3.5); $\beta$-xylosidase and $\alpha$-arabinofuranosidase were found to be more active at a $\mathrm{pH}$ value of 5.6 , while xylanase and $\beta$-glucosidase preferred higher $\mathrm{pH}$ values of 6.0 and 6.5 , respectively. 
Table 3. Main biochemical properties of enzymatic activities produced by $T$. thermostercoris strain BUFF grown on standard glucose growth media.

\begin{tabular}{lccc}
\hline Enzymes & $\begin{array}{c}\text { Optimum } \\
\text { Temperature (Range) }\end{array}$ & $\begin{array}{c}\text { Optimum pH } \\
\text { (Range) }\end{array}$ & $\begin{array}{c}\text { Molecular Weight } \\
\text { (kDa) }\end{array}$ \\
\hline Xylanase & $80^{\circ} \mathrm{C}\left(60-85^{\circ} \mathrm{C}\right)$ & $6.0(3.5-6.2)$ & $250,150,100$ \\
\hline$\beta$-xylosidase & $70^{\circ} \mathrm{C}\left(50-80^{\circ} \mathrm{C}\right)$ & $5.6(4.0-7.0)$ & 120 \\
\hline$\alpha$-arabinofuranosidase & $70^{\circ} \mathrm{C}\left(60-90^{\circ} \mathrm{C}\right)$ & $5.6(4.0-9.0)$ & 250 \\
\hline Acetyl-xylan esterase & $70^{\circ} \mathrm{C}\left(60-90^{\circ} \mathrm{C}\right)$ & $3.5(3.0-6.0)$ & 50 \\
\hline$\beta$-glucosidase & $60^{\circ} \mathrm{C}\left(35-75^{\circ} \mathrm{C}\right)$ & $6.5(5.0-8.5)$ & n.d. \\
\hline n.d.: not determined. & & &
\end{tabular}

The activity gels indicated the presence of three bands both in the case of xylanase (Figure 9, lane $A$ at 250, 150, $100 \mathrm{kDa}$ ) and of acetyl-xylan esterase (Figure 9, Lane $\mathrm{C}$ at $200,120,48 \mathrm{kDa})$; on the other hand, the presence of one band for both $\beta$-xylosidase and $\alpha$-arabinofuranosidase (120 and $50 \mathrm{kDa}$, Figure 9, lane B and D, respectively) was evidenced.

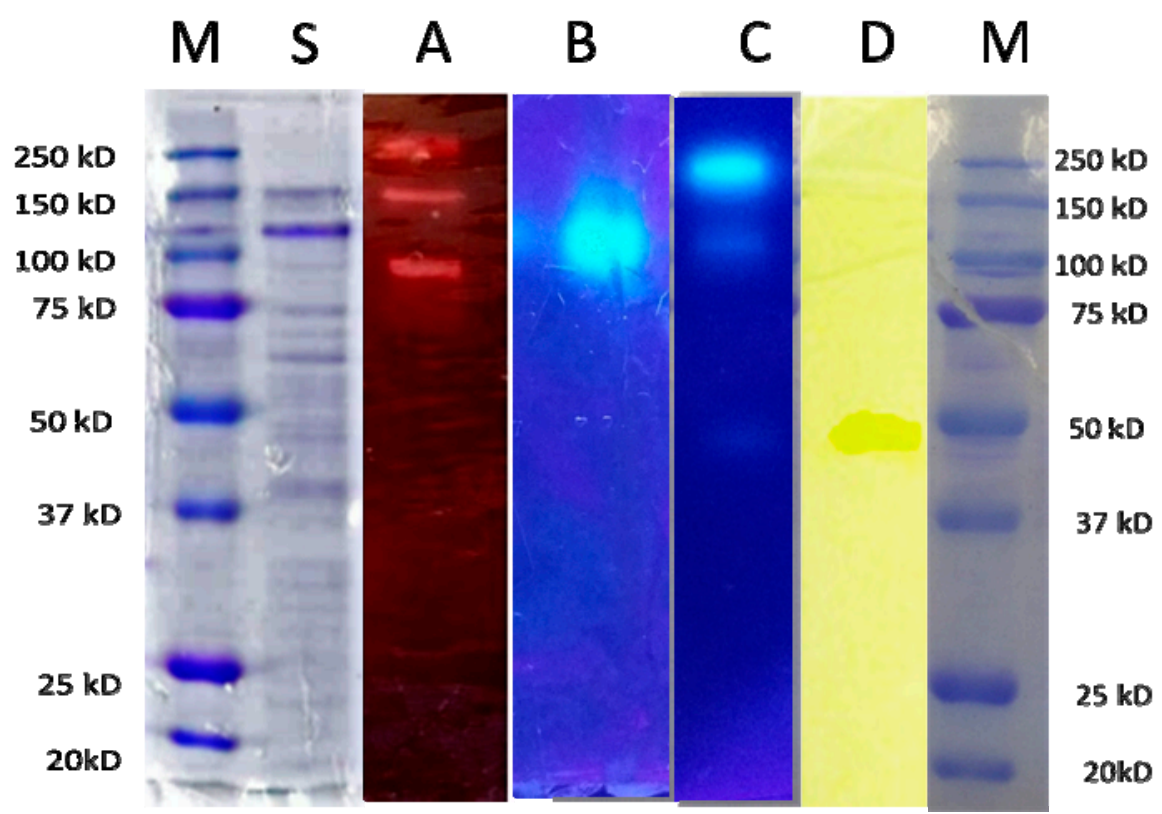

Figure 9. Sodium dodecyl sulphate-polyacrylamide gel electrophoresis (SDS-PAGE) of PP( $\left.\mathrm{NH}_{4}\right)_{2} \mathrm{SO}_{4}$ $(10 \mu \mathrm{g})$ of cell free supernatant obtained from standard growth conditions (glucose) (Lane S) and zymographic analyses of xylanase (Lane A), $\beta$-xylosidase (Lane B), $\alpha$-arabinofuranosidase (Lane C) and acetyl-xylan esterase (Lane D). Lanes M, molecular mass markers. The detection of the bands was carried out according to the procedure reported in the Materials and Methods section.

Most Thermoanaerobacterium strains possess xylanase activity [38]. Xylanase activity of $T$. thermostercoris strain BUFF was comparable to those previously reported in $T$. thermosaccharolyticum strain NOI-1 and T. saccharolyticum strain JW/SL-YS 485, of which the crude enzyme exhibited 2.55 and $0.36 \mathrm{U} / \mathrm{mg}$ xylanase activity, respectively $[39,40]$. Furthermore, the crude enzymes of strain BUFF exhibited up to 100-fold greater xylanase activity than that reported in T. xylanolyticum strain B6A-RI $(0.065 \mathrm{U} / \mathrm{mg})$ and T. brockii strain HTD4 (0.003 U/ mg) [38]. In the genus Thermoanaerobacterium, strains equipped with multi-enzymatic systems capable of digesting lignocellulose are also described; a thermophilic anaerobic bacterium, Thermoanaerobacterium thermosaccharolyticum strain NOI-1 when grown on xylan showed a multienzyme complex consisting of xylanase, $\beta$-xylosidase, $\alpha$-L-arabinofuranosidase, $\beta$-glucosidase and cellobiohydrolase $[40,41]$. 
In order to assess the thermal stability of the enzymes, the extracellular PP $\left(\mathrm{NH}_{4}\right)_{2} \mathrm{SO}_{4}$ samples of xylanase, $\beta$-xylosidase, $\alpha$-arabinofuranosidase and acetyl-xylan esterase, obtained from $T$. thermostercoris grown on standard glucose growth media and from fennel waste medium, were pre-incubated at temperature range $65-80^{\circ} \mathrm{C}$ at various time intervals. Subsequently, the samples were tested under standard conditions and the percentage of residual activity, compared to the non-pre-incubated ones, was calculated. As shown in Table 4 , in the case of extracellular enzyme preparation from glucose medium, the half-life of xylanase was reached after $4 \mathrm{~h}$ of pre-incubation at a temperature of $75^{\circ} \mathrm{C}$, while for the $\beta$-xylosidase and $\alpha$-arabinofuranosidase activities after $60 \mathrm{~min}$ of pre-incubation the half-life was reached at 70 and $80^{\circ} \mathrm{C}$, respectively. The acetyl-xylan esterase activity was less thermostable, as $50 \%$ of activity was reached only after $10 \mathrm{~min}$ of incubation at $80{ }^{\circ} \mathrm{C}$ (Table 4). In the case of $\left(\mathrm{PP}\left(\mathrm{NH}_{4}\right)_{2} \mathrm{SO}_{4}\right)$ extracellular enzyme preparation from fennel waste medium, for xylanase and $\alpha$-arabinofuranosidase a $50 \%$ of activity was reached after $240 \mathrm{~min}$ at a temperature of $75^{\circ} \mathrm{C}$ and $60 \mathrm{~min}$ at a temperature of $80^{\circ} \mathrm{C}$, respectively; for $\beta$-xylosidase and acetyl-xylanesterase, residual activity of $51 \%$ and $44 \%$ was reached after 60 and $10 \mathrm{~min}$ of incubation at a temperature of 75 and $80^{\circ} \mathrm{C}$, respectively.

Table 4. Residual xylanase, $\beta$-xylosidase, $\alpha$-arabinofuranosidase and acetyl-xylan-esterase activities in relation to temperature and time of pre-incubation.

\begin{tabular}{lcccc}
\hline Enzymes & $\begin{array}{c}\text { Temperature } \\
\left({ }^{\circ} \mathbf{C}\right)\end{array}$ & $\begin{array}{c}\text { Pre-Incubation } \\
\text { Time (min) }\end{array}$ & \multicolumn{2}{c}{$\begin{array}{c}\text { Residual Activity } \\
\text { (\%) }\end{array}$} \\
\hline Xylanase & 75 & 240 & $54^{*}$ & $50^{* *}$ \\
\hline$\beta$-xylosidase & 70 & 60 & $47^{*}$ & $51^{* *}$ \\
\hline$\alpha$-arabinofuranosidase & 80 & 60 & $45^{*}$ & $50^{* *}$ \\
\hline Acetyl-xylanesterase & 80 & 10 & $47^{*}$ & $44^{* *}$ \\
\hline
\end{tabular}

* $\left(\mathrm{PP}\left(\mathrm{NH}_{4}\right)_{2} \mathrm{SO}_{4}\right)$ extracellular enzyme preparation from glucose medium. ${ }^{* *}\left(\mathrm{PP}\left(\mathrm{NH}_{4}\right)_{2} \mathrm{SO}_{4}\right)$ extracellular enzyme preparation from fennel waste medium.

\subsection{Bioconversion of Hemicellulose Fractions from Arundo Donax and Cynara Cardunculus}

The partially purified $\left(\mathrm{PP}\left(\mathrm{NH}_{4}\right)_{2} \mathrm{SO}_{4}\right)$ extracellular enzyme of $T$. thermostercoris strain BUFF, produced by using fennel wastes for cell growth, was used to hydrolyze the hemicellulosic fraction deriving from the maceration in $\mathrm{KOH} 2 \mathrm{~N}$ for $72 \mathrm{~h}$ of the rhizome of $A$. donax and of the leaves and stems of $C$. cardunculus. The reaction mixtures, after incubation, were tested for the production of reducing sugars, and the hydrolysis yields were expressed as a percentage with respect to the initial quantity present in the substrates. In the case of the hemicellulosic fraction of $A$. donax, $48 \%$ bioconversion occurred, while for $C$. cardunculus it was $65 \%$. The enzymatic pool of the anaerobic bacterium $T$. thermostercoris strain BUFF was able to degrade the hemicellulosic component of the tested substrates (Table 5).

Table 5. Enzymatic hydrolyses of hemicellulose fractions from Arundo donax and Cynara cardunculus performed by using enzymes from $T$. thermostercoris strain BUFF.

\begin{tabular}{lccl}
\hline Substrate & RS $\left(\mathbf{T}_{\mathbf{f}}\right)(\mathbf{m g})$ & RS $(\%, w / w)$ \\
\hline CK & $5.2 \pm 0.016$ & 65 \\
AK & $3.84 \pm 0.012$ & 48 & \\
\hline $\mathrm{CK}=$ Cynara cardunculus hemicellulose extract; AK $=$ Arundo donax & hemicellulose extract; \\
$\mathrm{RS}=$ reducing sugars yield $(\% w / w$, with respect to initial substrate amount). &
\end{tabular}

Subsequently, the reaction mixtures were analyzed by thin layer chromatography (TLC). An increase in the hydrolysis products between time zero and final time (after $24 \mathrm{~h}$ of incubation) was evident (Figure S2); this difference was marked above all in the reaction mixture in which the polymer fractions were used as substrate. The most abundant hydrolyses products were xylose, xylobiose and xylotriose. Most of the microbially investigated $\beta$-xylosidases showed a strong xylose inhibition [42]. Conversely, $T$. ther- 
mostercoris strain BUFF $\beta$-xylosidase produced xylose displaying low substrate inhibition according to some recently investigated $\beta$-xylosidase activities [43] suggesting a possible use of T. thermostercoris strain BUFF $\beta$-xylosidase for the industrial sector. Degradation of lignocellulosic agro-industrial residues by means of complex hemicellulolytic enzymes is a promising approach providing efficient biomass decomposition for subsequent conversion to value-added products [44].

\section{Conclusions}

The anaerobic thermophile Thermoanaerobacterium thermostercoris strain BUFF is an interesting microbial cell factory for its capability to produce industrially relevant bioproducts with great economic value, especially in the green chemistry field. One main issue in this field is represented by the sustainable production of biofuels, for example bioethanol from lignocellulosic biomass. This work demonstrated that the sustainable production of $T$. thermostercoris cell biomass and its cellulolytic enzymes could be achieved by using residual biomass from the agroindustry sector. Moreover, we also found that $T$. thermostercoris could directly utilize raw vegetable wastes (such as energy crops' residues) for biohydrogen and bioethanol production. Experimental data revealed a powerful enzymatic pool comprising thermophilic xylanase, $\beta$-xylosidase, $\alpha$-arabinofuranosidase, $\beta$-glucosidase, $\alpha$-galactosidase, $\beta$-galactosidase and $\beta$-fucosidase activities suitable to a wide $\mathrm{pH}$ range that could serve as an excellent green factory for bioprocesses, in which value-added by-products are produced from food wastes. These enzymes proved to be very effective for the bioconversion of the hemicellulose fraction from dedicated crop biomass into xylooligomers and fermentable sugars. Therefore, they give this microorganism great potential in biotechnological fields as a catalyst for bioprocessing purposes. Nevertheless, there are still many opportunities for increasing the scientific value of this microbial system as a cell factory by means of exploring its genome as well as its high expression of enzymatic activities through cloning.

Supplementary Materials: The following are available online at https:/ / www.mdpi.com/article / 10.3390/resources10110115/s1, Figure S1: Glass fermenter connected to a thermostat water bath, a reflux condenser and to an exit system containing $\mathrm{NaOH}$ solution. Note that in order to purify $\mathrm{H}_{2}$ from $\mathrm{H}_{2} \mathrm{~S}$, gas produced during fermentation process first passes through a flask containing $\mathrm{NaOH}$ solution (2M) and a second flask containing distilled water. Figure S2: Thin layer chromatography analyses of hydrolysis products obtained by the enzymatic pool of the strain BUFF after $24 \mathrm{~h}$ of incubation at $60^{\circ} \mathrm{C}$ on the hemicellulosic fractions recovered from Cynara cardunculus and Arundo donax biomass. $\mathrm{X}$ : xylose standard; $\mathrm{X}_{2}$ : xylobiose standard; $\mathrm{X}_{3}$ : xylotriose standard; $\mathrm{X}_{4}$ : xylotetraose standard; $X_{5}$ : xylopentose standard; $X_{6}$ : xylohexose standard; G: glucose standard; $\mathrm{C} \mathrm{T}_{0}$ : reaction mixture containing the hemicellulosic fraction of $C$. cardunculus at zero incubation time; $C \mathrm{~T}_{24}$ : reaction mixture containing the hemicellulosic fraction of $C$. cardunculus after $24 \mathrm{~h}$ of incubation; $\mathrm{A}$ $\mathrm{T}_{0}$ : reaction mixture containing the hemicellulosic fraction of $A$. donax at zero incubation time; $\mathrm{A} \mathrm{T}_{24}$ : reaction mixture containing the hemicellulosic fraction of $A$. donax after $24 \mathrm{~h}$ of incubation. Symbols delimiting the bands are visible.

Author Contributions: Conceptualization, I.F., A.P. and L.L. (Licia Lama); methodology, I.F., L.L. (Licia Lama) and L.L. (Luigi Leone); investigation, I.R., I.F. and L.L. (Luigi Leone); resources, A.P. and L.L. (Licia Lama); data curation, I.F., I.R. and L.L. (Luigi Leone); writing-original draft preparation, A.P., P.D.D. and I.F.; writing-review and editing, A.P., I.F., P.D.D. and L.L. (Licia Lama); supervision, B.N.; project administration, A.P. and B.N.; funding acquisition, A.P., B.N. and L.L. (Licia Lama). All authors have read and agreed to the published version of the manuscript.

Funding: This work was partially funded by the project PON03PE_00107 BioPoliS (Development of green technologies for production of BIOchemicals and their use in preparation and industrial application of POLImeric materials from agricultural biomasses cultivated in a sustainable way in Campania region) funded by MIUR (Italian Ministry of University and Research).

Institutional Review Board Statement: Not applicable.

Informed Consent Statement: Not applicable. 
Data Availability Statement: Data availability belongs to the authors.

Acknowledgments: The authors thank Maria Rita Canfora for financial management and administrative project coordination.

Conflicts of Interest: The authors declare no conflict of interest.

\section{References}

1. Maina, S.; Kachrimanidou, V.; Koutinas, A. A roadmap towards a circular and sustainable bioeconomy through waste valorization. Curr. Opin. Green Sustain. Chem. 2017, 8, 18-23. [CrossRef]

2. Caldeira, C.; Vlysidis, A.; Fiore, G.; De Laurentiis, V.; Vignali, G.; Sala, S. Sustainability of food waste biorefinery: A review on valorisation pathways, techno-economic constraints, and environmental assessment. Bioresour. Technol. 2020, $312,123575$. [CrossRef] [PubMed]

3. Cristóbal, J.; Caldeira, C.; Corrado, S.; Sala, S. Techno-economic and profitability analysis of food waste biorefineries at European level. Bioresour. Technol. 2018, 259, 244-252. [CrossRef] [PubMed]

4. Liguori, R.; Faraco, V. Biological processes for advancing lignocellulosic waste biorefinery by advocating circular economy. Bioresour. Technol. 2016, 215, 13-20. [CrossRef]

5. Kamm, B. Biorefineries-their scenarios and challenges. Pure. Appl. Chem. 2014, 86, 821-831. [CrossRef]

6. Kamm, B.; Kamm, M. Principles of Biorefineries Mini-Review. Appl. Microbiol. Biotechnol. 2004, 64, 137-145. [CrossRef]

7. Xiong, X.; Yu, I.K.M.; Tsang, D.C.W.; Bolan, N.S.; Sik, O.Y.; Igalavithana, A.D.; Kirkham, M.B.; Kim, K.H.; Vikrant, K. Value-added chemicals from food supply chain wastes: State-of-the-art review and future prospects. Chem. Eng. Sci. 2019, 375, 121983. [CrossRef]

8. Di Donato, P.; Finore, I.; Poli, A.; Nicolaus, B.; Lama, L. The production of second generation bioethanol: The biotechnology potential of thermophilic bacteria. J. Clean. Prod. 2019, 233, 1410-1417. [CrossRef]

9. Di Donato, P.; Buono, A.; Poli, A.; Finore, I.; Abbamondi, G.R.; Nicolaus, B.; Lama, L. Exploring Marine Environments for the Identification of Extremophiles and Their Enzymes for Sustainable and Green Bioprocesses. Sustainability 2019, 11, 149. [CrossRef]

10. Di Donato, P.; Taurisano, V.; Poli, A.; Gomez d'Ayala, G.; Nicolaus, B.; Malinconico, M.; Santagata, G. Vegetable wastes derived polysaccharides as natural eco-friendly plasticizers of sodium alginate. Carbohydr. Polym. 2020, 229, 115427. [CrossRef]

11. Cimini, D.; Argenzio, O.; D'Ambrosio, S.; Lama, L.; Finore, I.; Finamore, R.; Pepe, O.; Faraco, V.; Schiraldi, C. Production of succinic acid from Basfia succiniciproducens up to the pilot scale from Arundo donax hydrolysate. Bioresour. Technol. 2016, 222, 355-360. [CrossRef] [PubMed]

12. Pagliara, V.; Nasso, R.; Di Donato, P.; Finore, I.; Poli, A.; Masullo, M.; Arcone, R. Lemon peel polyphenol extract reduces interleukin6-induced cell migration, invasiveness, and matrix metalloproteinase-9/2 expression in human gastric adenocarcinoma mkn-28 and ags cell lines. Biomolecules 2019, 9, 833. [CrossRef] [PubMed]

13. Finore, I.; Poli, A.; Di Donato, P.; Lama, L.; Trincone, A.; Fagnano, M.; Mori, M.; Nicolaus, B.; Tramice, A. The hemicellulose extract from Cynara cardunculus: A source of value-added biomolecules produced by xylanolytic thermozymes. Green Chem. 2016, 18, 2460-2472. [CrossRef]

14. Poli, A.; Finore, I.; Romano, I.; Gioiello, A.; Lama, L.; Nicolaus, B. Microbial Diversity in Extreme Marine Habitats and Their Biomolecules. Microorganisms 2017, 5, 25. [CrossRef] [PubMed]

15. Urbieta, M.S.; Donati, E.R.; Chan, K.G.; Shahar, S.; Sin, L.L.; Goh, K.M. Thermophiles in the genomic era: Biodiversity, science, and applications. Biotechnol. Adv. 2015, 33, 633-647. [CrossRef]

16. Bala, A.; Singh, B. Cellulolytic and xylanolytic enzymes of thermophiles for the production of renewable biofuels. Renew. Energy 2019, 136, 1231-1244. [CrossRef]

17. Kumar, S.; Dangi, A.K.; Shukla, P.; Baishya, D.; Khare, S.K. Thermozymes: Adaptive strategies and tools for their biotechnological applications. Bioresour. Technol. 2019, 278, 372-382. [CrossRef]

18. Singh, V.; Singh, M.P.; Verma, V.; Singh, P.; Srivastava, R.; Singh, A.K. Characteristics of Cold Adapted Enzyme and Its Comparison with Mesophilic and Thermophilic Counterpart. Cell Mol. Biol. 2016, 62. [CrossRef]

19. Di Donato, P.; Fiorentino, G.; Anzelmo, G.; Tommonaro, G.; Nicolaus, B.; Poli, A. Re-Use of Vegetable Wastes as Cheap Substrates for Extremophile Biomass Production. Waste Biomass. Valor. 2011, 2, 103-111. [CrossRef]

20. Barreca, F. Use of giant reed Arundo Donax L. in rural constructions Agricultural. Agric. Eng. Int. CIGR J. 2012, 14, 46-52.

21. Fernández, J.; Curt, M.D.; Aguado, P.L. Industrial applications of Cynara cardunculus L. for energy and other uses. Ind. Crops. Prod. 2006, 24, 222-229. [CrossRef]

22. Romano, I.; Di Pasquale, L.; Orlando, P.; Lama, L.; d'Ippolito, G.; Pascual, J.; Gambacorta, A. Thermoanaerobacterium thermostercus sp. nov., a new anaerobic thermophilic hydrogen producing bacterium from buffalo-dung. Extremophiles 2010, 14, 233-240. [CrossRef]

23. Romano, I.; Di Pasquale, L.; Orlando, P.; Lama, L.; d'Ippolito, G.; Pascual, J.; Gambacorta, A. Thermoanaerobacterium thermostercus corrig. Thermoanaerobacterium thermostercoris. List of new names and new combinations previously effectively, but not validly, published. Int. J. Syst. Evol. Microbiol. 2011, 61, 2563-2565. [CrossRef]

24. Wolin, E.A.; Wolin, M.J.; Wolfe, R.S. Formation of methane by bacterial extract. J. Biol. Chem. 1963, 238, 2882-2886. [CrossRef] 
25. Bradford, M.M. A rapid and sensitive method for the quantification of microgram quantities of protein utilizing the principle of protein-dye binding. Anal. Biochem. 1976, 72, 248-254. [CrossRef]

26. Bernfeld, P. Amylases $\alpha$ and $\beta$. Methods Enzymol. 1955, 1, 149e58. [CrossRef]

27. Lama, L.; Calandrelli, V.; Gambacorta, A.; Nicolaus, B. Purification and characterization of thermostable xylanase and $\beta$-xylosidase by the thermophilic bacterium Bacillus thermantarcticus. Res. Microbiol. 2004, 155, 283-289. [CrossRef] [PubMed]

28. Finore, I.; Vigneron, A.; Vincent, W.F.; Leone, L.; Di Donato, P.; Schiano Moriello, A.; Nicolaus, B.; Poli, A. Novel psychrophiles and exopolymers from permafrost thaw lake sediments. Microorganisms 2020, 8, 1282. [CrossRef]

29. Valkova, N.; Le' pine, F.; Labrie, L.; Dpont, M.; Beaudet, R. Purification and Characterization of PrbA, a New Esterase from Enterobacter cloacae Hydrolyzing the Esters of 4-Hydroxybenzoic Acid (Parabens). J. Biol. Chem. 2003, 278, 12779-12785. [CrossRef]

30. Laemmli, U.K. Cleavage of structural proteins during the assembly of the head of bacteriophage T4. Nature 1970, 227, 680-685. [CrossRef]

31. Martínez, T.F.; Alarcón, F.J.; Díaz-López, M.; Moyano, F.J. Improved detection of amylase activity by sodium dodecyl sulphatepolyacrylamide gel electrophoresis with copolymerized starch. Electrophoresis 2000, 21, 2940-2943. [CrossRef]

32. Lama, L.; Tramice, A.; Finore, I.; Anzelmo, G.; Calandrelli, V.; Pagnotta, E.; Tommonaro, G.; Poli, A.; Di Donato, P.; Nicolaus, B.; et al. Degradative actions of microbial xylanolytic activities on hemicelluloses from rhizome of Arundo donax. AMB Express. 2014, 4, 55. [CrossRef] [PubMed]

33. Murphy, C.D. The microbial cell factory. Organic. Biomol. Chem. 2012, 14, 1949-1957. [CrossRef]

34. Bibra, M.; Rathinam, N.K.; Johnson, G.R.; Sani, R.K. Single pot biovalorization of food waste to ethanol by Geobacillus and Thermoanaerobacter spp. Renew. Energy 2020, 155, 1032-1041. [CrossRef]

35. Nawirska, A.; Kwasniewska, M. Dietary fibre fractions from fruit and vegetable processing waste. Food Chem. 2005, 91, 221-225. [CrossRef]

36. Sanchez-Vazquez, S.A.; Hailes, H.C.; Evans, J.R.G. Hydrophobic Polymers from Food Waste: Resources and Synthesis. Polym. Rev. 2013, 53, 627-694. [CrossRef]

37. Tommonaro, G.; Poli, A.; De Rosa, S.; Nicolaus, B. Tomato derived polysaccharides for biotechnological applications: Chemical and biological approaches. Molecules 2008, 13, 1384-1398. [CrossRef] [PubMed]

38. Lee, Y.-E.; Jain, M.K.; Lee, C.; Zeikus, J.G. Taxonomic distinction of saccharolytic thermophilic anaerobes: Description of Thermoanaerobacterium xylanolyticum gen. nov., sp. nov., and Thermoanaerobacterium saccharolyticum gen. nov., sp. nov.; reclassification of Thermoanaerobium brockii, Clostridium thermosulfurogenes, and Clostridium thermohydrosulfiricum ElO0-69 as Thermoanaerobacter brockii comb. nov., Thermoanaerobacterium thermosulfurigenes comb. nov., and Thermoanaerobacter thermohydrosulfuricus comb. nov., respectively; and transfer of Clostridium thermohydrosulfuricum 39E to Thermoanaerobacter ethanolicus. Int. J. Syst. Evol. Microbiol. 1993, 43, 41-51.

39. Shao, W.; Deblois, S.; Wiegel, J. A high molecular weight, cell-associated xylanase isolated from exponentially growing Thermoanaerobacterium sp. strain JW/SL-YS485. Appl. Environ. Microbiol. 1995, 61, 937-940. [CrossRef] [PubMed]

40. Chimtong, S.; Tachaapaikoon, C.; Pason, P.; Kyu, K.L.; Kosugi, A.; Mori, Y.; Ratanakhanokchai, K. Isolation and characterization of endocellulase-free multienzyme complex from newly isolated Thermoanaerobacterium thermosaccharolyticum strain NOI-1. J. Microbiol. Biotechnol. 2011, 21, 284-292. [CrossRef] [PubMed]

41. Harnvoravongchai, P.; Singwisut, R.; Ounjai, P.; Aroonnual, A.; Kosiyachinda, P.; Janvilisri, T.; Chankhamhaengdecha, S. Isolation and characterization of thermophilic cellulose and hemicellulose degrading bacterium, Thermoanaerobacterium sp. R63 from tropical dry deciduous forest soil. PLoS ONE 2020, 15, e0236518. [CrossRef]

42. Wongwilaiwalin, S.; Rattanachomsri, U.; Laothanachareon, T.; Eurwilaichitr, L.; Igarashi, Y.; Champreda, V. Analysis of a thermophilic lignocellulose degrading microbial consortium and multi-species lignocellulolytic enzyme system. Enzyme Microb Technol. 2010, 47, 283-290. [CrossRef]

43. Bhalla, A.; Bischoff, K.M.; Sani, R.K. Highly thermostable GH39 $\beta$-xylosidase from a Geobacillus sp. strain WSUCF1. BMC Biotechnol. 2014, 14, 963. [CrossRef] [PubMed]

44. Shao, W.; Xue, Y.; Wu, A.; Kataeva, I.; Pei, J.; Wu, H.; Wiegel, J. Characterization of a novel beta-xylosidase, XylC, from Thermoanaerobacterium saccharolyticum JW/SL-YS485. Appl. Environ. Microbiol. 2011, 77, 719-726. [CrossRef] [PubMed] 